\title{
Labour Market Performance and Start-Up Costs: OECD Evidence
}

\author{
Paloma Lopez-Garcia
}




\begin{abstract}
This paper is intended to make a contribution to the empirical literature explaining the rise of unemployment since the 1970s in western economies by means of interactions between shocks and institutions. The contribution is twofold. First, the impact of a general feature of developed economies that has been surprisingly neglected in the literature is analyzed, namely, the employment shift from industry and agriculture to services. The second contribution of the paper is the focus on the interaction of that shock with the administrative burdens on firm creation. The working hypothesis is that countries that impose high costs on the creation of new companies are not able to create enough jobs in the service sector to successfully absorb the workers released from the agriculture and industry sector. The result is higher unemployment.
\end{abstract}

Keywords: Macroeconomics of unemployment; Panel data; Startup costs.

JEL Classification: J63, J64, J65, E24, K2.

This paper was produced as part of the Centre's Technology and Growth Programme. The Centre for Economic Performance is financed by the Economic and Social Research Council.

\title{
Acknowledgements
}

.I would like to thank my supervisor Christopher Pissarides for his restless support and encouragement. I would also like to thank all the participants of the Center for Economic Studies Seminar for their valuable comments. Marc Mündler and Sascha Becker deserve special mention for their patience, and precious help, with econometric issues. This paper is from my Ph.D. Thesis, written at the Centre for Economic Performance (LSE) with financial support of the Bank of Spain.

Paloma Lopez-Garcia is a member of the Centre for Economic Performance, London School of Economics. Contact email: paloma.lopez@ie.edu

\section{Published by}

Centre for Economic Performance

London School of Economics and Political Science

Houghton Street

London WC2A $2 \mathrm{AE}$

All rights reserved. No part of this publication may be reproduced, stored in a retrieval system or transmitted in any form or by any means without the prior permission in writing of the publisher nor be issued to the public or circulated in any form other than that in which it is published.

Requests for permission to reproduce any article or part of the Working Paper should be sent to the editor at the above address.

(C) P. Lopez-Garcia, submitted 2002

ISBN $075301713 \mathrm{X}$

Individual copy price: $£ 5$ 


\section{Introduction}

Robert Solow once said that one of the few good ways to test analytical ideas is to see whether they can make sense of international differences in institutional structure and historical development. This paper follows that advise, as do most of the large literature aimed at explaining the unusual and persistent increase in the unemployment rate from the 1970s in virtually all western capitalist economies.

In the 1970s the discussion was dominated by a shock story. Supply shocks of the 1970s and 1980s and the contractional macroeconomic policies to fight inflation were blamed for unemployment. But shocks across countries are not likely to vary enough to explain the observed differences in labour market performance. And the effect of shocks on unemployment is in any case temporary. Then how can one explain the persistence on the one hand and the different unemployment experiences across countries on the other?

The focus moved to labour market institutions, ignoring shocks all together sometimes. But the "usual suspects", the unemployment insurance system, the employment protection legislation or the union power were already in place when European unemployment was below the North-American one. There are three possible answers to that. First, labour market rigidities have become worse over time. It is true that some institutions, as the benefit insurance system or the tax wedge, have grown consistently in most OECD countries. ${ }^{1}$ But others such as employment protection legislation or union density have decreased in the last decade (after an initial period of increase). The second way out could be that labour market rigidities impact on labour performance with a lag. The rise of unemployment in the early 70 s could be then the result of rigidities introduced in the market ten years before.

The third answer, however, is lately the most popular: labour market rigidities were not so important in the past because there were no adverse shocks. Differences in labour market outcomes must be due to differences in the way that countries respond to similar shocks, which depends ultimately on the country specific institutions. It is the interaction of shocks with institutions what can explain the persistence of the shocks and the different labour market performance evolution across economies, after being hit by

\footnotetext{
${ }^{1}$ By "increase" or "growth" of institutions it is meant a change that makes labour markets more "rigid" as could be an extension of the time unemployed receive benefits or an increase in the tax wedge. The opposite holds with "decrease".
} 
similar shocks. The first economists in picking this idea up were Michael Bruno and Jeffrey Sacks in their 1985 book The Economics of Worldwide Stagflation where they focused on the interaction of the 1970s oil price shocks with the nature of collective bargaining.

This paper is intended to make a contribution to this line of research. The contribution is twofold. First, the impact of a general feature of developed economies that has been surprisingly neglected in the literature is analyzed, namely, the employment shift from industry and agriculture to services. The second contribution of the paper is the focus on the interaction of that shock with the administrative burdens on firm creation, start-up costs from now on.

The working hypotheses is that countries which impose high costs on the creation of new companies are not able to create enough jobs in the service sector to successfully absorb the workers released from the agriculture and industry sector. The result is higher unemployment.

The employment shift towards the service sector is a very well documented fact. Viktor Fuchs published in 1968 his path-breaking study The Service Economy. Around that time, Baumol published in the American Economic Review his paper "Unbalanced Growth," where the possible causes of the wide-spread shift of labour from industry and agriculture to the service sector were laid out. ${ }^{2}$

Baumol sorted economic activities into two groups: technologically progressive activities in which innovations, capital accumulation and economies of scale lead to increases in labour productivity (production sector); and constant productivity activities where labour is not a mean but the end so innovation can hardly increase productivity (service sector). The increase in labour productivity in the former sector brings in an increase in wages that is then spread to the overall economy. The constant productivity sector cannot compensate the rise in wages so production costs and prices increase. There are several effects at stake. First, the labour productivity growth is generating wealth that will be spent in services and non-services. Second, the relative increase in the service prices is inducing people to substitute away from services. As long as the substitution effect is not "too large" (the service demand is price-inelastic), the overall demand for services will

\footnotetext{
${ }^{2}$ See also [2] where a third sector of "asymptocally stagnation", with a mix of progressive and stagnant inputs, was introduced. In [11] Baumol's unbalanced growth and Kaldor's balcanced growth are reconcile.
} 
not decrease. To keep production in a sector with constant or decreasing productivity, labour has to be shifted from the high productivity sector.

Figure 1 shows the unweighted OECD average of manufacturing to service labour productivity and manufacturing to service price deflator. The pattern shown, which reproduces nicely Baumol predictions, is a feature of every country in the sample.

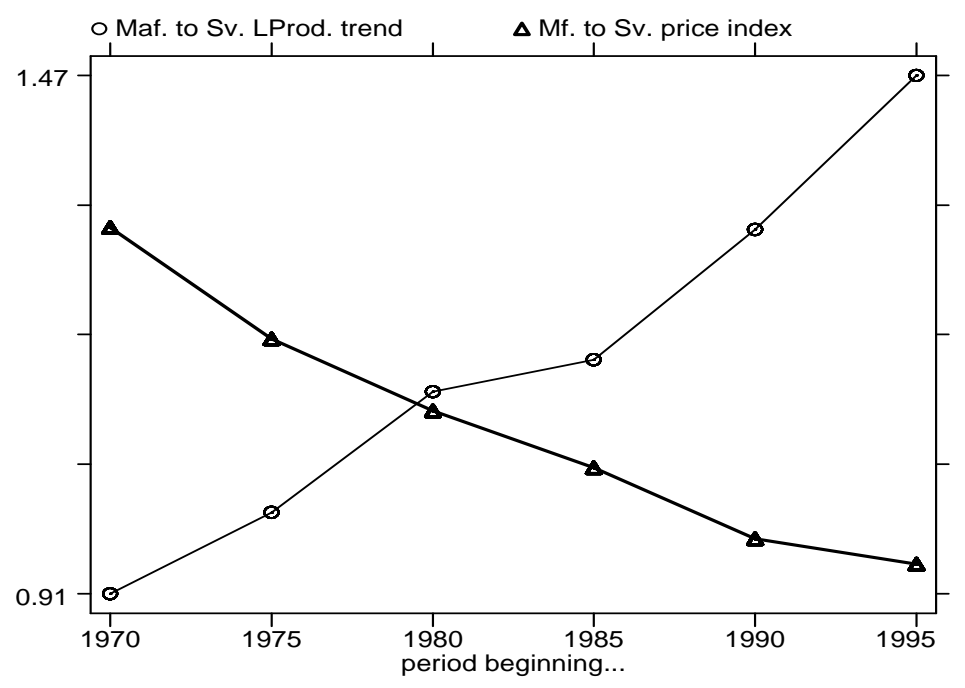

Figure 1: Manufacturing to service labour productivity and price index. Average OECD

Following Baumol we claim that the employment shift into services was the outcome of an exogenous shock: the slower productivity growth in services relative to non-service sectors. This approach is consistent with the arguments linking total factor productivity growth slowdown with unemployment but it emphasizes the differential productivity growth in services and the rest of the economy. ${ }^{3}$ Rather than on the overall fall in the supply or demand of jobs, the focus is on the shift of jobs and workers from non-service to service activities.

Figure 2 shows the annualized growth from 1970 to 1997 of total employment compared to the annualized growth of working age population (WAP)

\footnotetext{
${ }^{3}$ See $[27]$ and more recently [7]. The argument is that the slowdown in total productivity growth has not been matched with a slowdown of wages and therefore unemployment has increased.
} 
in seven OECD countries and the EU average.

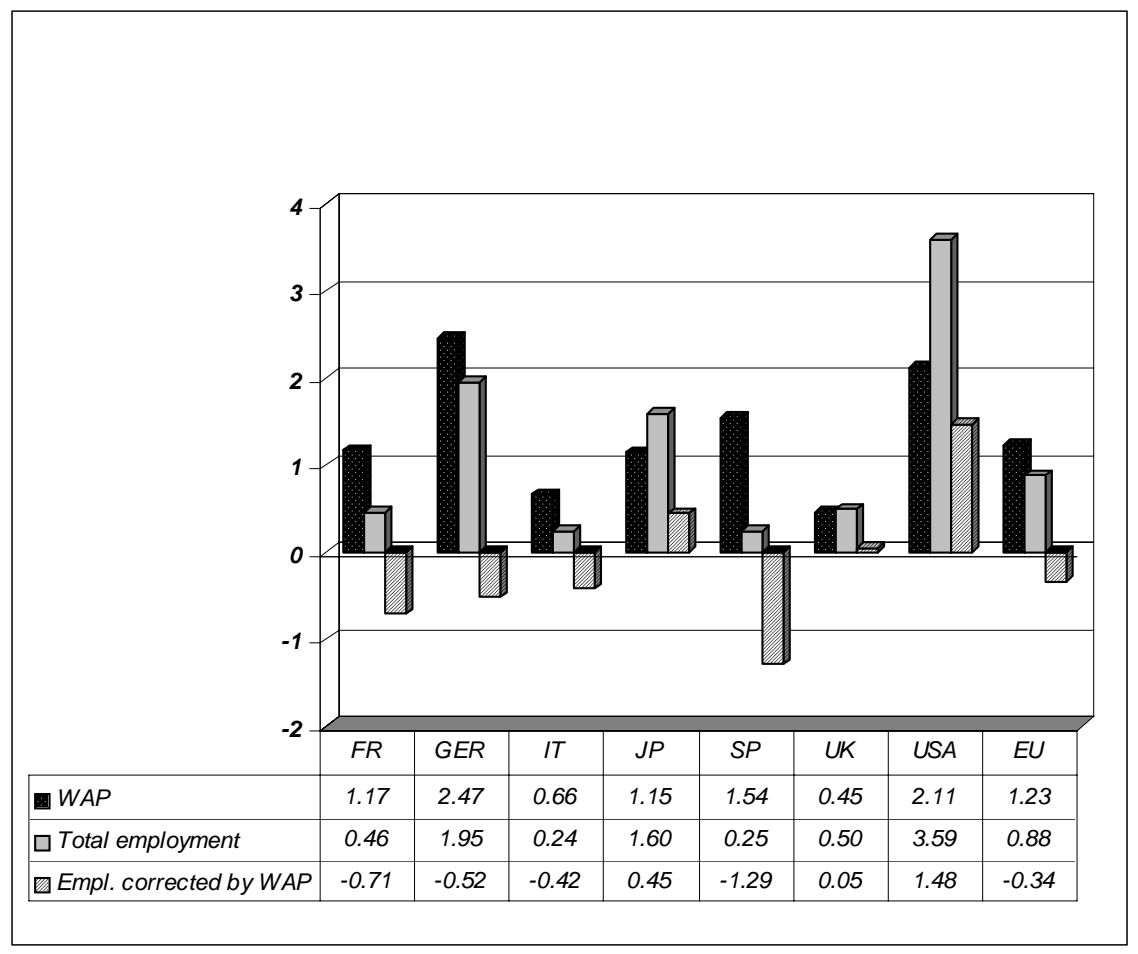

Figure 2: Employment and working age population (WAP) annualized growth, in \%. 1970-97

Only Japan, the UK and the USA were able to create enough jobs to compensate for the increase in working age population. Spain had an unfortunate combination of very poor employment growth and rather high increase in working age population. The question is, what is behind those differences in employment growth? Figure 3 shows the annualized contribution of each economic sector to total employment growth. The sector contributions are calculated as the annualized sector employment growth weighted by the sector's initial share of total employment.

Service employment growth accounts for most of the employment growth. The poor employment performance of Spain is the result of a very large release of workers from the agriculture, and to a lesser extent from the industry sector, along with a below average service job creation. The impressive performance of the USA is due to an incredible ability to create jobs in the service sector and of a very limited (none) loss of employment in the non- 


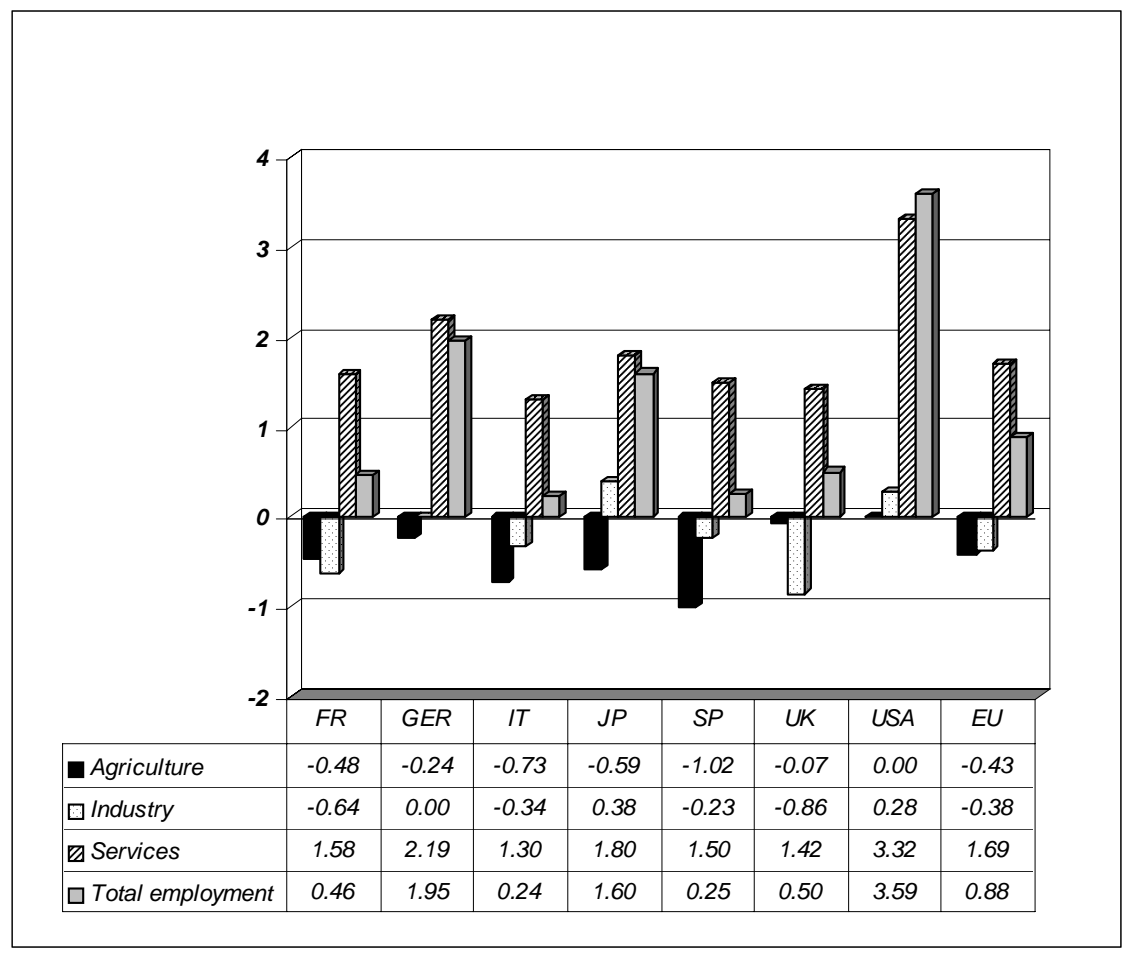

Figure 3: Annualized sector contribution to employment growth, in \%. 197097

service sectors. Marimon and Zilibotti [1998] calculated that almost $80 \%$ of the long-run employment differential growth across countries and industries is accounted by sector effects (different initial distribution of labour across industries) and only $20 \%$ by country effects.

The inability of the major European economies to create enough jobs to absorb the increasing supply of labour has been well documented. Krueger and Pischke [1997], for example, decompose the growth of employment between population growth and other reasons and show that population growth in Europe does not create jobs at the same rate as it does in USA. They go further in the paper and claim that the reason for this is not, as usually believed, Europe's wage rigidity. That explanation would imply that unemployment would have to increase most in Europe among groups whose wages have fallen most in USA. But that is not the case: the unemployment rate of the low-skilled group of workers (relative to the high-skilled one) is roughly the same in Europe and the United States. Krueger and Pischke rather sug- 
gest that the problem is the existence of restrictions on bringing new products to the market or on starting new businesses. When these restrictions are in place, the increase in labour supply is not traduced in an equivalent increase in the number of employers, and unemployment results.

This brings us to the second contribution of this paper, which is to relate the inability to create "enough" service jobs in some countries to their institutions governing firm creation and other product market regulations.

The 1994 McKinsey Global Institute report "Employment Performance" was perhaps the first study which claimed that product market regulations, as opposed to labour market regulations, were very important in explaining poor job creation in the service sector in Europe. Also in 1994, the OECD Jobs Study affirmed that "new jobs are likely to appear in the service sector, which already accounts for more than half of total employment in most OECD countries(..). New jobs must certainly be generated by the private sector, because in nearly all countries budget deficits and resistance to tax increases rule out significant expansion of the public sector (...). Efforts to improve the capacity of economies to create jobs should focus on facilitating the development and use of technology; working time flexibility; encouragement of entrepreneurship and a general review of policies that may be hampering job creation." 4

The OECD went further in this direction publishing in 1998 a monograph titled "Fostering Entrepreneurship." They also have very recently published comparable data on product market regulations (details are given in the next section) and consistent data on firm dynamics for 10 OECD countries. The paper by Scarpetta et al. [2002] is an extremely recent application of both data-sets. In that paper the authors test the role that policy and institutional settings in product and labour markets play for productivity and firm dynamics. They find that industry productivity performance is negatively affected by strict product market regulations. The second important finding is that more cumbersome regulation on entrepreneurial activity and costs of adjusting the workforce seem to negatively affect the entry of new small firms and their posterior expansion.

The current paper claims that countries which suffered the biggest rise in unemployment are the ones that failed to provide policies and institutions that were conductive to the employment in services. A key policy in this

\footnotetext{
${ }^{4}$ The italics are mine. See the electronic version of [22] at http://www1.oecd.org/sge/min/job94/tabcont.htm
} 
respect is the regulation of business openings. Service employment occurs on average in smaller and more decentralized establishments than manufacturing and successful new job creation in services requires the setting up of new companies. ${ }^{5}$ Countries where starting a business is cumbersome have failed to accommodate the employment shift from manufacturing and agriculture into services, at the cost of higher unemployment.

The paper follows very closely the methodology used by Blanchard and Wolfers in their highly acknowledge paper of 2000 (that paper will be referred as $B \& W$ from now on). In that paper the authors use a panel of 20 countries to explain the evolution of unemployment in the OECD from the 1960s via the interaction of shocks and institutions. The shocks included are the decrease in annual TFP growth, the increase in long-term interest rate, and the shift in labour demand. The institutions include the unemployment insurance system, the cost of hiring and firing, wage bargaining characteristics and active labour market policies.

Taking as a starting point the B\&W model, we substitute the aggregate TFP growth by the differential productivity growth in manufacturing and services, and add one institution, namely, start-up costs. The purpose is to test whether start-up costs, when interacted with the shift of employment from non-services to services, can explain the poor service employment performance and high unemployment rate of some countries.

The next section describes with some detail the data used in the estimations. Section three explains the methodology and empirical results. Section four concludes.

\section{$2 \square$ Data Description}

A panel data-set building on the one constructed and analyzed by B\&W has been put together. ${ }^{6}$ We drew data from B\&W for unemployment, labour market institutions and shocks. Product Market Indicators from the OECD were added. The three macroeconomic shocks of B\&W were complemented

\footnotetext{
${ }^{5}$ In 1995 the average service firm size in the Eurpean Union was of 5 employees, as compared to 16 employees in industry and energy. The data for United States is in 1997 of 21 and 56 employees respectively. As Scarpetta et al. [2002] confirm in their paper, American entrant firms are smaller than European ones but then expand much more.

${ }^{6}$ Both the data-set and the original Stata program are available in Olivier Blanchard's or Justin Wolfer's web-page. Please refer to their work for technical details concerning the construction of the variables.
} 


\begin{tabular}{lcc}
\hline \hline Countries & $\begin{array}{c}\text { Change in } \\
\text { unemployment: }\end{array}$ & $\begin{array}{c}\text { Change in service } \\
\text { employment: }\end{array}$ \\
\hline France & 7.37 & 8.73 \\
Germany & 8.79 & 8.88 \\
Italy & 7.77 & 8.62 \\
Spain & 19.99 & 6.23 \\
UK & 5.35 & 11.19 \\
USA & .09 & 14.45 \\
Japan & 1.94 & 11.40 \\
\hline
\end{tabular}

Source: OECD Annual Labour Force

Note: Unemployment is expressed in \% of labor force.

Service employment is in \% of working age population

Table 1: Change in unemployment and service employment, in percentage

with a fourth shock intended to capture the sectorial shift from non-service to service activities over the last decades. An unbalanced data-set is available for 20 OECD countries along 28 years, from 1970 to $1997 .^{7}$ The countries included in the analysis are Australia, Austria, Belgium, Canada, Denmark, Finland, France, Germany, Ireland, Italy, Japan, the Netherlands, Norway, New Zealand, Portugal, Spain, Sweden, Switzerland, United Kingdom and United States.

There are three dependent variables: unemployment rate, service and manufacturing employment ratios. All data come from the OECD annual Labour Force Survey. Unemployment numbers are those gathered in the National Labour Force surveys. Service employment comprises civilian employment employed in sectors such as wholesale and retail trade; restaurants and hotels; transport, storage and communications; financing, insurance, real state and business services; and community, social and personal services. We have also carried out the regressions using industry civilian employment instead of manufacturing employment; the results are very robust.

Table 1, shows the change from 1970 to 1997 of unemployment and service employment in the United States, Japan and five large European countries: France, Germany, Italy, Spain and UK.

Countries that experienced the most limited increases in service employ-

\footnotetext{
${ }^{7}$ Blanchard and Wolfers [2000] work with a data-set that covers the period 1960-1997. However, the unavailability of data on sector employment, production and price indexes in earlier years made it advisable to reduce the observation period to 1970-1997.
} 
ment over the period 1970-97, like Spain or Italy, are also the ones that suffered the largest increases in unemployment in the same period. Indeed, the correlation between both growth rates (using all countries in the panel) is of $(-0.7)$. That correlation encourages further research to understand why service employment did not increase as much in some countries and to what extent that explains the different unemployment experiences across countries.

\subsection{Institutions}

\subsubsection{Labour Market institutions}

Data for labour market institutions come originally from Nickell [1997]. Nickell presents averages of eight labour market institutions for 1983-1988 and for 1989-1994. B\&W use the average of both periods as the time-constant value of each labour market institution. We discuss briefly the definitions.

- Employment Protection Legislation (EPL): The source of the index is the OECD Jobs Studies published in 1994. The OECD ranked countries according to the legal framework governing firing and hiring. The index is the ranking of 20 countries, 20 indicating the most strictly regulated country. The OECD measure comprises characteristics both of the individual and collective contract termination. That includes features as notice time and financial compensation, rights to appeal against termination or administrative procedures.

- Benefit Replacement Rate: Gross benefits for a single person under 50 , expressed as percentage of the most relevant wage (normally gross wage).

- Benefit Duration: It captures how long the unemployed are entitled to receive unemployment insurance. It is expressed in years. Four or more years are considered infinite duration.

- Active Labour Market Policies (ALMP): It refers to expenditures on activities for the unemployed that are aimed at helping them back into work. The numbers are expenditure per unemployed person taken as percentage of GDP per member of the labour force.

- Union Density: It shows the proportion of trade union members as percentage of total wage and salary earners. This variable alone does 
not give a good idea of the union influence in a country, though, since in many countries wage negotiations affect workers who are not union members. That is why we need to include as well the next variable.

- Union Coverage: This variable shows the share of workers actually affected by union bargaining. It takes three values. 1 means that only under $25 \%$ of workers is covered. 2 means that the percentage of covered employees is between 25 and $70 \%$. Lastly, 3 means that more than $70 \%$ of workers are effected by union negotiation on wages.

- Wage Bargaining Coordination: In each country the degree of employer and worker wage bargaining coordination is ranked from a low coordination index of 1 to a high coordination value of 3 .

- Tax burden on labour: This is a crude measure of the tax wedge between real labour costs and take home pay. It is the sum of the average payroll, consumption and income tax rates.

We have added to the labour market institutions presented above a proxy for the minimum wage level in the country. The idea is that the same argument that applies to start-up costs governs wage floors. That is, the failure to create enough jobs in the service sector could be due to the existence of wage floors, which prevented small firms from hiring more people. The proxy is the ratio of the first percentile of earnings distribution to the fifth percentile or median. The earnings dispersion data come from the OECD Employment Outlooks of 1993 and 1996. There is no data for Spain and Ireland, and data for the rest of the countries is very incomplete. Therefore, any comment has to be done with caution.

\subsubsection{Start-up costs}

The OECD has recently published an indicator of product market regulations for 21 OECD countries (excluding the new central and eastern European members, Korea, Mexico and Turkey); unfortunately, only for one year: 1998. The data come from responses of OECD countries to an ad hoc questionnaire and other sources. The information was grouped in the following regulatory domains:

\footnotetext{
${ }^{8}$ For a full description of the data-set see [19].
} 
- State control over business enterprises: Overall size of the public enterprise sector; existence and extent of special rights over business enterprises; legislative control over public enterprises; existence of price controls; and use of command and control regulations.

- Barriers to entrepreneurship: Features of the licensing and permit system; communication and simplification of rules and procedures; administrative burdens of corporate and sole-proprietors start-ups; industry specific administrative burdens; scope of legal barriers to entry and existence of antitrust exemptions for public enterprises.

- Barriers to international trade and investment: Barriers to share-ownership for non-resident operators; discriminatory procedures in international trade and competition policies; regulatory barriers to trade; and average tariffs.

To calculate the overall product market regulation index, each coded indicator was re-scaled to be between 0 and 6 . Then the indicators were aggregated into the summary indicators and finally into the overall indicator weighting each component according to its contribution to the overall variance in the data (factor analysis methodology).

The "barriers to entrepreneurship" indicator has three sub-domains: Regulatory and administrative opacity, barriers to competition, and administrative burdens on start-ups. The variable "administrative burdens on start-ups" is defined as "administrative burdens for corporations, for soleproprietorship and sector specific burdens," such as those present in the retail sector. The latter is a variable of interest regarding the current analysis because it includes administrative burdens, not only of corporations but also of sole-account proprietors, which is the legal form that most start-ups assume. This is an advantage over other possible data sources such as the one offered by Djankov et al. [2000]. In that paper the authors gather data on required procedures governing entry regulation as well as the cost in time and monetary terms of following those procedures. However, data refer only to limited liability companies, which is a handicap if what one want to study is the impact of those procedures on firm creation.

Hence, the OECD sub-domain "administrative burdens on start-ups" will be used in the analysis to proxy institutions governing firm creation. Recall that it is our claim that countries with large administrative burdens on firm 
creation were not able to create enough service jobs to absorb displaced workers from other economic sectors. However, and for the sake of comparison, the analysis will also be done using instead the overall index of product market regulations.

Figure 4 shows start-up costs in 1998 across OECD countries. Leading the classification is Italy, followed by France and Spain. The countries where opening a new business is easiest are UK, USA and Denmark.

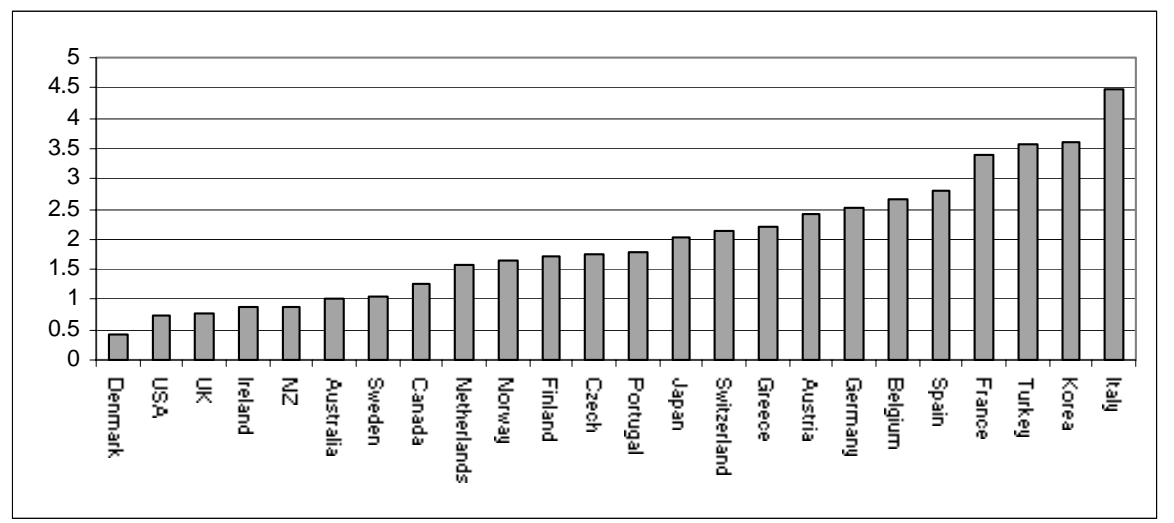

Figure 4: Administrative burdens on start-ups, OECD Index [0,6]. 1998

\section{2 $\square$ Macroeconomic shocks}

B\&W identify three negative macroeconomic shocks, that might have contributed to the increase in unemployment over the last decades: the decline in total factor productivity growth, the shift in labour demand, or equivalently, the increase in the capital share and, finally, the increase in long-term interest rate.

The Total Factor Productivity growth is calculated as the growth of the Solow residual for the business sector scaled by the labour share. From the early 70s, the TFP growth, specially in Europe, has slowed down. If workers and firms are slow to adapt to the slower growth of productivity, profits will decrease, and so will capital accumulation and employment. Capital shares started increasing in the 1980s in most European countries. There are two possible reasons. The first possibility ventured by Blanchard [1999] is a technological change biased to capital. The second one is a decrease in firms' labour hoarding (when firms employ too much labour at a given 
wage), maybe fostered by the historical lose of power of unions within Europe. Both possibilities lead to a decrease in labour demand and, therefore, to an increase in unemployment. Finally, the real interest rate, calculated as the long-term nominal rate on government bonds minus a five-year average of lagged inflation, has increased steadily since the beginning of the 80s.

Baumol [1967] claimed that the employment shift from non-service to services observed in the last decades was the result of the differential productivity growth in the different economic sectors. To be accurate, one should focus on the differential total factor productivity growth in manufacturing and services, rather than on the differential labour productivity growth. It is only total factor productivity changes that one can assume exogenous since labour productivity depends, among other things, on capital accumulation which is an endogenous variable. ${ }^{9}$ Using the OECD International Sector Database to construct sector TFP rates we have been able to put together an unbalanced panel of 13 countries, out of the 20 countries under analysis. ${ }^{10}$ That comes to around 50 observations when we run the regressions with five-year averages. Taking into account that there are at least 24 explanatory variables in the regression, that panel is clearly not sufficient to yield something meaningful about the impact of shocks and institutions.

Since capital stock changes only slowly, labour productivity is much more cyclical than total factor productivity. Hence one possible way of proceeding is to use a smoothed version of labour productivity as a proxy to total factor productivity. ${ }^{11}$ Figure 5 shows the ratio of manufacturing to service smoothed labour productivity and manufacturing to service total factor productivity evolution over time. The former is the average of 18 countries and the later is the average of 13 countries.

In spite of the different number of countries included, the evolution along time of both variables is similar; hence the regression with the labour productivity trend instead of the total factor productivity will point approximately in the right direction. However, we are aware of potential identification problems. To construct a better panel data-set of sector total factor productivity

\footnotetext{
${ }^{9}$ We thank Marc Mündler for intensive discussions about this point.

${ }^{10}$ We followed the methodology of Bernard and Jones [1996a] and [1996b] to construct sector TFP rates. They first calculate a base year manufacturing and service TFP, and then estimate the rest of the years using a Divisia-Tornquist multifactor productivity rate.

${ }^{11}$ The variable was smoothed using a Hodrick-Prescott filter. We used a lambda equal to 100 because the data have annual frequence. We also tried with other values such as 10 or 400 , also used in the literature, and results did not differ.
} 


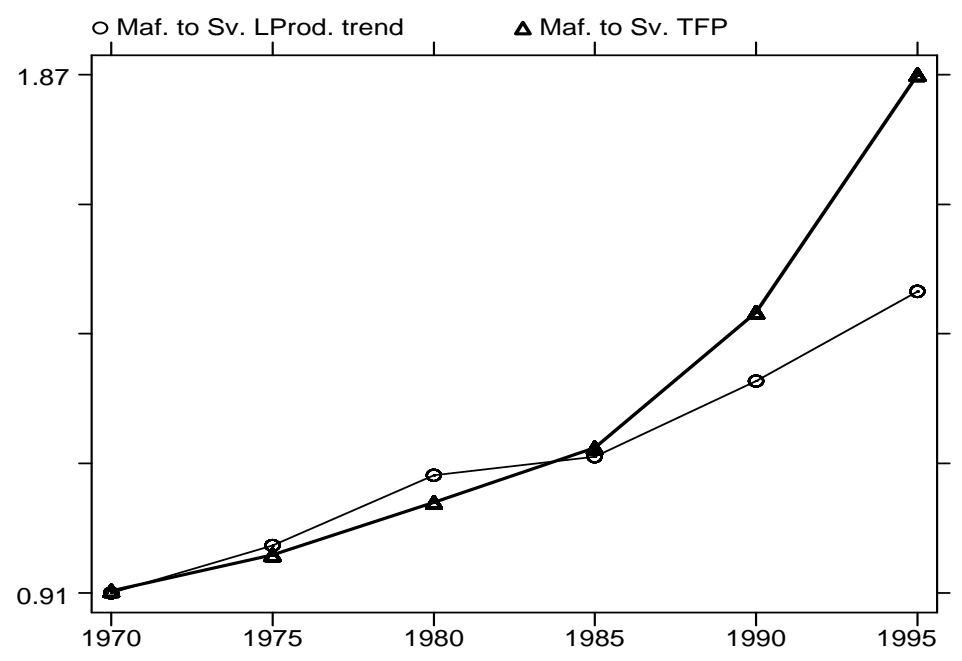

Figure 5: Manufacturing to service labour and total factor productivity

will be the next step in our research.

\section{Results}

The model to be estimated was first suggested by Blanchard [1999] in a Baffi Lecture in Rome titled "European Unemployment: the Role of Shocks and Institutions." In the lecture he defended the interaction between macroeconomic shocks with various labour market institutions as the best way to explain, first the persistence of the impact of shocks on unemployment, and second, the diverse impact of similar shocks in the OECD countries.

\subsection{Common unidentified shocks: a benchmark}

\subsubsection{Time-constant institutions}

To capture those interactions, the simplest model is as follows:

$$
u_{i t}=\sum_{i} \alpha_{i} c_{i}+d_{t}+\sum_{j} \gamma_{j}\left(d_{t} * X_{i}^{j}\right)+\epsilon_{i t}
$$

where $u_{i t}$ is the dependent variable (unemployment, service or manufacturing employment rates) in country $i$ at time $t, c_{i}$ are 20 country dummies, $d_{t}$ 
are time dummies, that is, common unidentified shocks ${ }^{12}$, and $X_{i}^{j}$ is the time-constant value over the period of the institution $j$ in country $i$. What matters in the estimation is not the value of the shock or the institution but the interaction between both of them. This is the most general specification since no specific shocks are imposed. Therefore it allows to isolate the impact of the institutions from that of the shocks on the dependent variables. Hence it will be used as a benchmark.

Notice that each institution is allowed to interact separately with the same linear combination of shocks. The model is therefore non-linear. ${ }^{13} \mathrm{~B} \& \mathrm{~W}$ estimate the model using non-linear least squares and do not correct for heteroscedasticity present in the regression. Although the coefficients are consistent, and therefore it is legitimate to use them to make estimations, they are not efficient, that is, with minimum variance, so the standard errors are not correct. In this paper the model will be estimated using an equivalent maximum likelihood function which allows for White's heteroscedasticityconsistent variances and standard errors.

Autocorrelation is only a problem in the regressions with common shocks, proxied by time dummies. The deviation from the average of the dependent variable, unemployment rate or sector employment rates, is clearly cyclical. In the first set of regressions time dummies are used, so there is nothing in the right-hand side of expression 1 to account for that cyclical behavior, hence the error term is autocorrelated. However, autocorrelation is corrected for when identified shocks instead of time dummies are introduced in the regression.

Tables 2, 3 and 4 show respectively the results for the unemployment, service and manufacturing regression. Five year averages have been taken (with the exception of the last period which only comprises 1995-1997) to smooth out short-term fluctuations. All institutions are expressed in deviations to the cross-country mean. Wage bargaining coordination and active labour market policies have been multiplied by $(-1)$ so the expected impact of all institutions on unemployment is positive. Country and time dummies

\footnotetext{
${ }^{12}$ The first period is left out so it becomes the constant. Therefore the country dummies can be interpreted as the unemployment (or sector employment rates) in the first period.

${ }^{13}$ We could try to make it linear in the following way,

$u_{i t}=\sum_{i} \alpha_{i} c_{i}+d_{t}+\gamma_{1} \beta_{1}\left(d_{1} * X_{i}^{1}\right)+\gamma_{1} \beta_{2}\left(d 2 * X_{i}^{1}\right)+\gamma_{2} \beta_{1}\left(d_{1} * X_{i}^{2}\right)+\gamma_{2} \beta_{2}\left(d_{2} * X_{i}^{2}\right)+\ldots+\epsilon_{i t}$ where we have written the example for two time dummies or shocks $\left(d_{1}\right.$ and $d_{2}$ with coefficients $\beta_{1}$ and $\beta_{2}$ ) and two institutions $\left(X_{i}^{1}\right.$ and $X_{i}^{2}$ with coefficients $\gamma_{1}$ and $\left.\gamma_{2}\right)$. But we would then have to impose non-linear restrictions on the coefficients, so $\frac{\gamma_{1} \beta_{1}}{\beta_{1}}=\frac{\gamma_{1} \beta_{2}}{\beta_{2}}$.
} 
Dependent variable: Unemployment rate

\begin{tabular}{|c|c|c|c|c|c|}
\hline & 1 & 2 & 3 & 4 & 5 \\
\hline B. Duration & $.23(.04)$ & $.26(.05)$ & $.29(.05)$ & $.19(.04)$ & $.29(.06)$ \\
\hline B.R.Rate & $.02(.00)$ & $.02(.01)$ & $.03(.01)$ & $.00(.00)$ & $.02(.00)$ \\
\hline EPL & $.05(.02)$ & $.01(.02)$ & $-.01(.02)$ & $.02(.02)$ & $.03(.02)$ \\
\hline U.Density & $.01(.01)$ & $.02(.01)$ & $.02(.01)$ & $.02(.01)$ & $.01(.01)$ \\
\hline Tax Wedge & $.02(.01)$ & $.01(.01)$ & $.00(.01)$ & $.02(.01)$ & $.02(.01)$ \\
\hline Coordination & $.26(.06)$ & $.33(.06)$ & $.38(.05)$ & $.12(.07)$ & $.32(.05)$ \\
\hline U.Coverage & $.07(.19)$ & $.04(.19)$ & $.01(.19)$ & $-.07(.20)$ & $.04(.21)$ \\
\hline ALMP & $.02(.01)$ & $.01(.01)$ & $.01(.01)$ & $.02(.01)$ & $.01(.01)$ \\
\hline Start-up costs & & $.38(.12)$ & & & \\
\hline SUC*initial nsv & & & $.73(.16)$ & & \\
\hline Minimum Wage & & & & $1.4(.9)$ & \\
\hline Product Market Regul. & & & & & $.49(.17)$ \\
\hline Observations & 117 & 117 & 117 & 105 & 117 \\
\hline $\begin{array}{l}\text { Notes: Standard errors } \\
\text { When minimum wages }\end{array}$ & $\begin{array}{l}\text { bracket } \\
\text { introd }\end{array}$ & 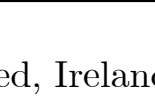 & G & & \\
\hline
\end{tabular}

Table 2: Unemployment Regression, common shocks and time-constant institutions

were included in all regressions.

Five different regressions have been run with each dependent variable. The first one replicates that of B\&W. The results are very similar although not exactly the same since the observation period is not the same. The second regression adds to the eight labour market institutions the administrative burdens on start-ups provided by the OECD (more concretely, the data is from 1998, which is taken as the time-constant value of the institution). The third regression substitute start-up costs by the interaction between startup costs and the initial non-service employment share of the working age population. We claim that the combination of large shifts of employment from non-service to service sector with administrative barriers to firm creation hampers employment creation, or equivalently, fosters unemployment. In the fourth regression start-up costs have been substituted by minimum wages (proxied by the first percentile of the earnings distribution to the median wage). Regression five includes the overall product market regulation index.

There is a lot of information in the three tables shown above so let us take 
Dependent variable: Service employment ratio

\begin{tabular}{|c|c|c|c|c|c|}
\hline & 1 & 2 & 3 & 4 & 5 \\
\hline B. Duration & $-.10(.03)$ & $-.12(.03)$ & $-.13(.03)$ & $-.10(.03)$ & $-.10(.03)$ \\
\hline B.R.Rate & $-.00(.00)$ & $-.01(.00)$ & $-.01(.00)$ & $-.00(.00)$ & $-.00(.00)$ \\
\hline EPL & $-.03(.01)$ & $-.01(.01)$ & $-.01(.01)$ & $-.03(.01)$ & $-.04(.01)$ \\
\hline U.Density & $-.01(.00)$ & $-.01(.00)$ & $-.01(.00)$ & $-.01(.00)$ & $-.01(.00)$ \\
\hline Tax Wedge & $-.01(.01)$ & $-.00(.01)$ & $.00(.01)$ & $-.00(.01)$ & $-.01(.01)$ \\
\hline Coordination & $-.13(.04)$ & $-.17(.04)$ & $-.17(.04)$ & $-.08(.06)$ & $-.13(.04)$ \\
\hline U.Coverage & $.19(.14)$ & $.19(.13)$ & $.21(.13)$ & $.15(.12)$ & $.19(.14)$ \\
\hline ALMP & $-.00(.01)$ & $.00(.01)$ & $.00(.01)$ & $.00(.01)$ & $-.00(.01)$ \\
\hline Start-up costs & & $-.21(.09)$ & & & \\
\hline SUC*initial nsv & & & $-.32(.13)$ & & \\
\hline Minimum Wage & & & & $.87(.83)$ & \\
\hline Product Market Regul. & & & & & $.01(.12)$ \\
\hline Observations & 117 & 117 & 117 & 105 & 117 \\
\hline
\end{tabular}

Table 3: Service Regression, common shocks and time-constant institutions

Dependent variable: Manufacturing employment ratio

\begin{tabular}{|c|c|c|c|c|c|}
\hline & 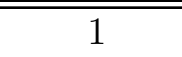 & 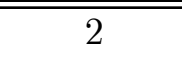 & 3 & 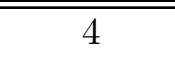 & 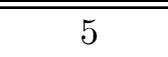 \\
\hline B. Duration & $.19(.06)$ & $.24(.05)$ & $.26(.05)$ & $.19(.06)$ & $.24(.07)$ \\
\hline B.R.Rate & $-.01(.00)$ & $.00(.00)$ & $.00(.00)$ & $-.01(.01)$ & $-.01(.00)$ \\
\hline EPL & $-.02(.02)$ & $-.08(.02)$ & $-.09(.02)$ & $-.01(.02)$ & $-.03(.02)$ \\
\hline U.Density & $-.02(.01)$ & $-.00(.01)$ & $-.00(.01)$ & $-.01(.01)$ & $-.02(.01)$ \\
\hline Tax Wedge & $.01(.01)$ & $-.00(.01)$ & $-.01(.01)$ & $.01(.01)$ & $.01(.01)$ \\
\hline Coordination & $-.17(.07)$ & $-.05(.06)$ & $-.07(.06)$ & $-.04(.06)$ & $-.12(.07)$ \\
\hline U.Coverage & $.02(.22)$ & $.00(.18)$ & $-.03(.19)$ & $-.10(.19)$ & $.01(.21)$ \\
\hline ALMP & $-.02(.01)$ & $-.02(.01)$ & $-.03(.01)$ & $-.01(.01)$ & $-.02(.01)$ \\
\hline Start-up costs & & $.61(.13)$ & & & \\
\hline SUC*initial nsv & & & $.86(.2)$ & & \\
\hline Minimum Wage & & & & $2.6(.85)$ & \\
\hline Product Market Regul. & & & & & $.41(.25)$ \\
\hline Observations & 117 & 117 & 117 & 105 & 117 \\
\hline $\begin{array}{l}\text { Notes: Standard errors } \\
\text { When minimum wages }\end{array}$ & $\begin{array}{l}\text { bracket } \\
\text { introd }\end{array}$ & $\mathrm{J}$ & 10 & & \\
\hline
\end{tabular}

Table 4: Manufacturing Regression, common shocks and time-constant institutions 
you slowly through the most interesting results. The first important remark is that the unemployment and the service results look like two sides of the same coin. When benefit duration, replacement rate, employment protection legislation and wage bargaining coordination are positive and significant in the unemployment regression, they show as negative and significant in the service regression. This result confirms what the first look at the data suggested.

Benefit duration is very robust and significant in all regressions. Countries where unemployed receive long benefits experience more unemployment. More interesting may be the service and manufacturing regressions. Countries with longer benefits than average are countries with less service and more manufacturing employment.

The positive sign of benefit duration, the case is the same for the minimum wage, in the manufacturing regression is a very robust, and interesting, result. It has been reported before that high and long unemployment benefits increase the reservation wage of workers. A high reservation wage means that workers are less willing to accept low-paid jobs in the service sector and prefer instead to queue in the manufacturing sector. Thus, the shift from non-service to service economy is delayed.

Consequently the negative sign of benefit duration in the service regression is not surprising. However, there could be something else to the negative impact of benefits on service employment. The report of the Global Entrepreneurship Monitor of 2001 found that countries with generous unemployment insurance systems were systematically less "entrepreneurial". ${ }^{14}$ This was explained in the following way: There are two types of start-ups. One type is the result of a business opportunity and the other type is the result of desperation, of the need to make a living. Generous benefit systems are taking away part of the desperation of the unemployed and, therefore, decreasing the second type of start-ups. Hence, if we accept the intimate connection between start-ups and service sector job creation, generous benefit systems can be expected to decrease service employment.

Long unemployment benefits and high wage floors are normally the result of strong union power in the country. The regressions include three bargaining related variables: union density, union coverage and wage bargaining

\footnotetext{
${ }^{14}$ The Global Entrepreneurship Monitor is an international project led by Paul Reynolds (Babson College and the London Business School) aimed at measuring entrepreneurship across countries in a comparable way. See www.gemconsortium.org.
} 
coordination. The first remarkable fact is the lack of significance over all specifications of union coverage. The second remark is that both union density and wage bargaining coordination affect significantly service employment and unemployment, and are relatively unimportant in explaining manufacturing employment. This result is consistent with the observed impact of benefits and minimum wages: unionized countries have higher union premium, i.e. the relative wage in manufacturing is higher, which means that migration to the service sector has been slower.

Start-up costs, and the overall index of product market regulations, have a consistent positive and significant sign in the unemployment regression. The variable star-up costs is also negative in the service regression and positive in the manufacturing regression. Countries where starting a business is cumbersome have paid in terms of service employment, and of unemployment. The results are reinforced when instead of start-up costs we run the regression with the interaction of start-up costs with initial non-service employment. Start-up costs have a higher impact when the 1970 share of population of working age outside the service sector is larger. In other words, countries that had to go a long way from non-service to service economies paid a higher price in terms of unemployment for institutions that delayed the sectorial shift.

The impact of the overall index of product market regulations, however, differs from the one of start-up costs in both sector employment regressions. It is not significant in the service regression and it is significant only at $11 \%$ significance level (although positive, as the start-up costs) in the manufacturing one. Recall that the overall OECD index groups regulations that cover a much wider range of economic activities than start-up costs, such as state control over the private sector, barriers to international trade or existence of anti-trust exemptions for public enterprises. Some of those domains are not, or negatively, correlated to start-up costs so they are capturing different phenomena. ${ }^{15}$ Since service employment takes place at small local firms, some of the regulations included in the overall index do not apply, which could explain the non-significance of the variable in the service regression.

When start-up costs (or the interaction term) are included in the unemployment regression, several labour market institution variables drop. Most dramatic is the effect of start-up costs on employment protection legislation.

\footnotetext{
${ }^{15}$ For example, barriers to trade and start-up costs have a correlation coefficient equal to (-.03). The two sub-domain of barriers to entrepreneurship, "administrative opcity" and "administrative burdens on start-ups," have a correlation coefficient of (-.17).
} 


\begin{tabular}{l||c|cc|cc}
\hline \hline & \multirow{2}{*}{$\begin{array}{c}\text { Coefficients } \\
\text { from Table 2, } \\
\text { Variable }\end{array}$} & \multicolumn{2}{|c|}{$\begin{array}{c}\text { Range of variation } \\
\text { of institution }\end{array}$} & \multicolumn{2}{c}{$\begin{array}{c}\text { Implied range } \\
\text { of effect of shock }\end{array}$} \\
\cline { 2 - 6 } Time effect & .07 & & & & \\
B. Duration & .26 & -1.93 & 1.57 & -.50 & .41 \\
B.R. Rate & .02 & -46.35 & 32.65 & -1.11 & .78 \\
U.Density & .02 & -30.98 & 39.02 & -.52 & .65 \\
Coordination & .33 & -2.05 & 1.95 & -.68 & .65 \\
Start-up costs & .38 & -1.49 & 2.80 & -.57 & 1.07 \\
\hline Note: Only coefficients significant at $10 \%$ are included in table \\
\hline
\end{tabular}

Table 5: Estimated impact of institutions on unemployment after a common shock

Once start-up costs are introduced, EPL does not show up as significant again. This is so in almost all specifications we tried and therefore very robust, and is consistent with evidence based on job flows. The high correlation between start-up costs and EPL (correlation coefficient of 0.73) may explain the significance of EPL in other aggregate studies. When minimum wages are included, instead of start-up costs, EPL reappears as significant, which seems to confirm the previous remark.

To give an idea of the magnitude of the coefficients, Table 5 reproduces in its second column the estimation results for the model of unemployment with start-up costs (Table 2, regression 2). The third column of the table shows the variation range of each independent variable. The variation is in terms of deviations to the cross-country mean, which is taken as reference point. The fourth column shows the impact of the same shock on the country with the "best" and the "worst" institutional setting, i.e. on the countries with the largest -negative and positive- deviations to the cross-country mean. For example, Denmark is the country with the lowest start-up costs and Italy the one with the "worst" or largest value of the institution among all countries in the sample. The estimations indicate that the time dummy would increase unemployment by $7 \%$ in a country with the average value of all institutions. The country with the highest start-up costs would have an additional -relative to the country with average start-up costs- increase in unemployment of $1.07 \%$. Denmark, however, would see an increase in unemployment $0.57 \%$ smaller than the country with the average value of start-up costs. 


\begin{tabular}{lrrrrr}
\hline \hline Unemployment: common shocks & Belgium & Italy & Japan & UK & USA \\
\hline Actual increase, 1970-97 & $12 \%$ & $8 \%$ & $2 \%$ & $5 \%$ & $0 \%$ \\
Predicted increase, 1970-97 & $14.7 \%$ & $6.1 \%$ & $1.7 \%$ & $7.8 \%$ & $0.1 \%$ \\
\hline $\begin{array}{l}\text { Percentage explained by time } \\
\text { (given average institutions) }\end{array}$ & $7 \%$ & $7 \%$ & $7 \%$ & $7 \%$ & $7 \%$ \\
Percentage explained by institutions & $7.7 \%$ & $-0.9 \%$ & $-5.3 \%$ & $0.8 \%$ & $-6.9 \%$ \\
\hline Benefit system & $3.3 \%$ & $-11.3 \%$ & $-3.1 \%$ & $-0.6 \%$ & $-4.7 \%$ \\
EPL & $0.5 \%$ & $0.8 \%$ & $-0.2 \%$ & $-0.3 \%$ & $-0.8 \%$ \\
Union activity & $1.1 \%$ & $1 \%$ & $-2.2 \%$ & $4.4 \%$ & $1.1 \%$ \\
Tax Wedge & $0.1 \%$ & $0.9 \%$ & $-0.9 \%$ & $-0.3 \%$ & $-0.3 \%$ \\
ALMP & $0.2 \%$ & $0.2 \%$ & $0.5 \%$ & $0.3 \%$ & $0.8 \%$ \\
Start-up Costs & $2.4 \%$ & $7.5 \%$ & $0.5 \%$ & $-2.7 \%$ & $-3 \%$ \\
\hline \hline
\end{tabular}

Table 6: Predicted increase in unemployment: contribution of institutions

Take the case of a particular country, for example Italy. The average unemployment rate in the first period of analysis, 1970-1975, was of 4\%. During the last period, 1995-1997, the average rate was $12 \%$. Hence unemployment increased 8 percentage points over the period of analysis. The model with common shocks and time-constant institutions predicts an unemployment increase of $6.1 \%$ in that same period. As the table above shows, 7 percentage points of that predicted increase are due to time shocks. The remaining responds to the Italian specific institutional framework. Table 6 shows the contribution to the predicted change in unemployment of each of the institutions analyzed in the paper for Italy and other four OECD countries.

Benefit duration and replacement rates have been merged into "Benefit system" and union coverage, union density and wage bargaining coordination conform the institution "Union activity." Following with the example of Italy, it is known that Italy barely had an unemployment benefit system at all for most of the postwar period, hence the negative contribution to the unemployment increase over the period. Union activity, employment protection legislation, the tax wedge and active labour market policies have all marginally contributed to the unemployment rise in Italy, according to our estimations. The single institution that can explain a substantial increase in Italian unemployment is start-up costs.

Turning to the remarkable unemployment performance of the United States, very well predicted by the model, we can see that it is almost entirely due to the lower than average benefit system and start-up costs. Belgium is 
the opposite case: its bad unemployment records are due to unemployment benefits and start-up costs well above the OECD average.

Hence, according to the model with common shocks and time-constant institutions, the two single labour market institutions that have contributed the most to the explanation of the diverse OECD unemployment evolution are the benefit system (benefit duration and replacement rate) and the startup costs of firms.

\subsection{Identified shocks}

We now turn to identify those shocks that before were left unidentified and captured by time dummies. The model to be estimated is as follows:

$$
u_{i t}=\sum_{i} c_{i}+\sum_{k} \beta_{k} S_{k i t}+\sum_{j} \gamma_{j}\left(\sum_{k} \beta_{k} S_{k i t} * X_{i}^{j}\right)+\epsilon_{i t}
$$

where $S_{k i t}$ is shock $k$ in country $i$ at time $t$. One can think about a composite of shocks that interacts with the labour market institutions. There are several candidates for "bad" shocks that might be responsible for the observed increase in unemployment in the OECD countries in the last three decades.

Blanchard [1999] and then B\&W identify three of those shocks: a slowdown in the total factor productivity growth; an increase in the long-term real interest rate; and finally, an increase in the capital share, or equivalently, a negative shift of labour demand. The focus of this paper is on sector differential productivity growth rather than on aggregate productivity slowdown. It is argued that manufacturing and service differential productivity growth is behind the observed employment shift to the service sector in developed economies. We claim that countries that did not have friendly institutions to service job creation were not able to absorb displaced workers from other sectors which resulted in higher unemployment.

To test that claim, the first of B\&W shocks, aggregate TFP growth, is substituted by the manufacturing to service TFP. Then the interaction of shocks with the labour market institutions and start-up costs is used as explanatory variables in the unemployment and sector employment regressions.

Sector TFP is proxied by the "filtered" sector labour productivity or labour productivity trend, as we explained with some detail in the section dedicated to the description of the data. In general terms the first and last 
Dependent variable: Unemployment rate

\begin{tabular}{lcccc}
\hline \hline & 1 & 2 & 3 & 4 \\
\hline Labour Demand Shift & $.09(.07)$ & $.07(.05)$ & $.09(.06)$ & $.05(.06)$ \\
LR interest rate & $.04(.09)$ & $.04(.09)$ & $.03(.09)$ & $.05(.09)$ \\
Manufacturing to service L.Prod. & $.07(.01)$ & $.07(.01)$ & $.07(.01)$ & $.08(.01)$ \\
B. Duration & $.26(.11)$ & $.35(.11)$ & $.29(.11)$ & $.44(.12)$ \\
B.R.Rate & $-.02(.01)$ & $-.00(.01)$ & $-.01(.01)$ & $-.02(.01)$ \\
EPL & $.02(.04)$ & $-.12(.08)$ & $.04(.04)$ & $-.09(.06)$ \\
U.Density & $.04(.01)$ & $.05(.01)$ & $.05(.01)$ & $.02(.01)$ \\
Tax Wedge & $-.03(.02)$ & $-.05(.02)$ & $-.03(.02)$ & $-.03(.01)$ \\
Coordination & $.09(.21)$ & $.19(.19)$ & $.10(.18)$ & $.04(.18)$ \\
U.Coverage & $-.26(.42)$ & $-.32(.43)$ & $-.07(.44)$ & $-.11(.38)$ \\
ALMP & $-.00(-01)$ & $-.03(.01)$ & $-.00(.01)$ & $-.03(.01)$ \\
Start-up costs & & $.97(.52)$ & & \\
Minimum Wage & & & $-4.2(2.1)$ & \\
Product Market Regulation & & & & $1.5(.68)$ \\
\hline Wald Test (3 shocks) & 78 & 78 & 76 & 78 \\
Observations & & & &
\end{tabular}

Notes: Standard errors in brackets.

When minimum wages are introduced, Ireland and Spain drop.

Table 7: Unemployment Regression: Identified shocks and time-constant institutions

period of data are missing for all countries, Ireland and Switzerland drop totally and Spain has only two periods of data available. Our data set is therefore badly reduced (from 106 to 78 observation in the best case) so the results of the estimations have to be taken with caution.

Tables 7, 8 and 9 show the estimation results of the model with three identified shocks, labour demand shift, long-term interest rate, and manufacturing to service labour productivity, and time-constant institutions. Column (1) shows the estimation of the model only with labour market institutions, column (2) includes start-up costs, column (3) substitutes start-up costs by minimum wages, and column (4) includes the OECD overall index of product market regulation, in place of the administrative burdens on start-ups.

All the three shocks are entered in levels and can be interpreted as deviations to the value in the first period of analysis, or as deviations to the country average. A Wald test to test for their joint significance has been performed and in all cases we can reject the hypotheses of all coefficients 
Dependent variable: Service employment ratio

\begin{tabular}{|c|c|c|c|c|}
\hline & 1 & 2 & 3 & 4 \\
\hline Labour Demand Shift & $.16(.07)$ & $.26(.13)$ & $.15(.07)$ & $.20(.09)$ \\
\hline $\mathrm{LR}$ interest rate & $.29(.11)$ & $.30(.14)$ & $.28(.11)$ & $.29(.12)$ \\
\hline Manufacturing to service L.Prod. & $.16(.01)$ & $.16(.01)$ & $.17(.02)$ & $.15(.02)$ \\
\hline B. Duration & $-.09(.04)$ & $-.12(.04)$ & $-.07(.05)$ & $-.14(.05)$ \\
\hline B.R.Rate & $.00(.00)$ & $-.01(.01)$ & $.00(.02)$ & $.00(.00)$ \\
\hline EPL & $-.03(.02)$ & $.07(.03)$ & $-.03(.02)$ & $.00(.04)$ \\
\hline U.Density & $-.01(.01)$ & $-.01(.00)$ & $-.00(.01)$ & $-.00(.01)$ \\
\hline Tax Wedge & $-.01(.01)$ & $.00(.01)$ & $-.01(.01)$ & $-.01(.01)$ \\
\hline Coordination & $.09(.11)$ & $.00(.09)$ & $.08(.13)$ & $.07(.11)$ \\
\hline U.Coverage & $-.11(.29)$ & $-.05(.29)$ & $-.02(.32)$ & $-.18(.32)$ \\
\hline ALMP & $.00(.01)$ & $.02(.01)$ & $.00(.01)$ & $.01(.01)$ \\
\hline Start-up costs & & $-.66(.26)$ & & \\
\hline Minimum Wage & & & $-2.0(2.6)$ & \\
\hline Product Market Regulation & & & & $-.50(.39)$ \\
\hline Wald Test (3 shocks) & 278 & 328 & 183 & 278 \\
\hline Observations & 78 & 78 & 76 & 78 \\
\hline
\end{tabular}

Table 8: Service Regression: Identified shocks and time-constant institutions 
Dependent variable: Manufacturing employment ratio

\begin{tabular}{|c|c|c|c|c|}
\hline & 1 & 2 & 3 & 4 \\
\hline Labour Demand Shift & $.03(.05)$ & $.04(.05)$ & $.03(.05)$ & $.05(.05)$ \\
\hline LR interest rate & $-.05(.08)$ & $-.05(.08)$ & $-.06(.09)$ & $-.05(.08)$ \\
\hline Manufacturing to service L.Prod. & $-.12(.01)$ & $-.12(.01)$ & $-.12(.01)$ & $-.12(.01)$ \\
\hline B. Duration & $.11(.06)$ & $.13(.07)$ & $.11(.06)$ & $.17(.07)$ \\
\hline B.R.Rate & $-.02(.01)$ & $-.01(.01)$ & $-.02(.01)$ & $-.02(.01)$ \\
\hline EPL & $-.03(.01)$ & $-.07(.03)$ & $-.04(.01)$ & $-.07(.03)$ \\
\hline U.Density & $.00(.01)$ & $.00(.01)$ & $-.00(.01)$ & $-.00(.01)$ \\
\hline Tax Wedge & $-.02(.01)$ & $-.02(.01)$ & $-.02(.01)$ & $-.02(.01)$ \\
\hline Coordination & $.07(.13)$ & $.11(.10)$ & $.09(.14)$ & $.07(.12)$ \\
\hline U.Coverage & $.22(.19)$ & $.22(.18)$ & $.24(.23)$ & $.24(.19)$ \\
\hline ALMP & $-.03(.01)$ & $-.03(.01)$ & $-.03(.01)$ & $-.04(.01)$ \\
\hline Start-up costs & & $.21(.22)$ & & \\
\hline Minimum Wage & & & $.29(1.1)$ & \\
\hline Product Market Regulation & & & & $.41(.36)$ \\
\hline Wald Test (3 shocks) & 165 & 162 & 143 & 164 \\
\hline Observations & 78 & 78 & 76 & 78 \\
\hline
\end{tabular}

Table 9: Manufacturing Regression: Identified shocks and time-constant institutions 
being zero.

The first remarkable thing is that the labour demand shift and the longterm interest rate are not significant in the unemployment and manufacturing regressions when sector labour productivity is controlled for. ${ }^{16}$ On the other hand, the manufacturing to service labour productivity is always very significant (t-statistics of about 10 in absolute value). That shock is positive in the unemployment regression, positive in the service regression and negative in the manufacturing regression. All signs are as expected since, according to Baumol [1967], the increase in manufacturing productivity relative to service caused the shift of employment from non-service to service sectors. Hence it explains the increase in service employment and the decrease in manufacturing employment. The second remarkable issue is to be found in the service regression. It has been mentioned that the increase in manufacturing to service labour productivity increases significantly service employment, as expected. The striking thing is that the two other shocks included in the analysis, labour demand shift and increase in the interest rate, also increase significantly service employment. The most likely explanation is the existence of a spurious relationship between the growth in service employment and the growth in the capital share and interest rate.

Turning directly to the administrative burdens on start-ups, the focus of this paper, we observe the following. The coefficient of start-up costs is higher than with unidentified shocks in all regressions. It is positive and significant at $10 \%$ significance level in the unemployment regression, very significant and negative, in the service regression, and positive but non-significant in the manufacturing regression. What these results are telling us is that the shift of employment from non-service to service activities had a very high cost in terms of service employment, reflected in overall unemployment, in countries where starting a business is more cumbersome than average.

The beauty is that when the regression is run with the aggregate TFP growth, as in Blanchard and Wolfers [2000], there is no evidence that countries with more administrative burdens on firm creation than the average have a worse service employment performance. ${ }^{17}$ Burdens on firm creation

\footnotetext{
${ }^{16}$ When aggregate TFP growth is included instead, the long-term interest rate is significant in all regressions. Labour demand shift is close to significance at $10 \%$ level in the unemployment regression. B\&W found the labour demand shift to be significant. However when heteroscedasticity is controlled for, the labour demand shift loses its significance.

${ }^{17}$ The estimations with aggregate TFP growth, instead of sector differential labour productivity growth, are available in [14].
} 
become significant only when interacted with a shock that caused the relocation of large numbers of workers in the service sector.

When the overall product market regulation index is included instead of start-up costs, the results change slightly. Product market regulations, when interacted with the sector differential productivity, increase significantly unemployment (this result is more significant than when start-up costs were included). The difference, as it was the case when regressions were run with time dummies, is to be found in the service regression, where product market regulations have a non-significant negative coefficient.

Countries with longer benefits than average create less jobs in the service sector (where the private initiative is very important), have a larger share of the working age population employed in the manufacturing firms and experience, in general, higher unemployment than an average country.

With respect to the rest of the institutions, the most remarkable changes from before are as follow. First, EPL is non-significant from the beginning in the unemployment regression (before it was significant when start-up costs were excluded). In the service regression, EPL goes from being negative and significant without start-up costs to positive and significant when they are included. When minimum wages are controlled for instead, the sign is again negative (although non-significant). Therefore the behavior observed before, when the EPL index systematically dropped out when start-up costs were introduced, is here amplified.

To get a feeling of the contribution of the three shocks analyzed in the section to the increase in unemployment, let us take a look in more detail to Italy -a country that has experienced a large relocation of workers into the service sector. The predicted rise of Italian unemployment over the period is of $7.25 \%$, much closer to the actual $8 \%$ than the predicted increase of the model with common unidentified shocks. Of those 7.25 percentage points, shocks (given average institutions) can explain a rise equal to $5.7 \%$ and institutions explain the remaining $1.5 \%$. The shift of employment to the service sector explains alone $5 \%$ points of the $5.7 \%$ corresponding to the shocks.

The large contribution of that shock is a feature of every country; in average it accounts for around $60 \%$ of the total predicted change in unemployment. That figure is quite close to the one given by Marimon and Zilibotti [1998], who calculated that almost $80 \%$ of the long-run employment differential growth across countries and industries is accounted by different initial distribution of labour across industries and only $20 \%$ by country effects. 


\begin{tabular}{lrrrrr}
\hline \hline Unemployment: Identified shocks & Belgium & Italy & Japan & UK & USA \\
\hline Actual increase, 1970-97 & $12 \%$ & $8 \%$ & $2 \%$ & $5 \%$ & $0 \%$ \\
Predicted increase, 1970-97 & $10 \%$ & $7.3 \%$ & $1 \%$ & $4.4 \%$ & $-0.2 \%$ \\
\hline $\begin{array}{c}\text { Percentage explained by shocks } \\
\text { (given average institutions) }\end{array}$ & $5.2 \%$ & $5.7 \%$ & $1.5 \%$ & $2.8 \%$ & $3 \%$ \\
\multicolumn{1}{c}{ Labour Demand Shift } & $-0.3 \%$ & $0.4 \%$ & $-0.1 \%$ & $-0.3 \%$ & $0.4 \%$ \\
Long-term Interest Rate & $0.1 \%$ & $0.2 \%$ & $0.1 \%$ & $0.1 \%$ & $0.1 \%$ \\
Manufacturing to service productivity & $5.4 \%$ & $5.1 \%$ & $1.5 \%$ & $3 \%$ & $2.5 \%$ \\
Percentage explained by institutions & $4.8 \%$ & $1.5 \%$ & $-0.5 \%$ & $1.7 \%$ & $-3.2 \%$ \\
\hline Benefit system & $2.8 \%$ & $-3.2 \%$ & $-1.1 \%$ & $1.6 \%$ & $-2 \%$ \\
EPL* & $-4.1 \%$ & $-6.6 \%$ & $0.5 \%$ & $1.1 \%$ & $3.4 \%$ \\
Union Activity* & $2.3 \%$ & $-0.3 \%$ & $-1 \%$ & $1.2 \%$ & $-1.3 \%$ \\
Tax wedge & $-0.2 \%$ & $-3.4 \%$ & $1 \%$ & $0.7 \%$ & $0.7 \%$ \\
ALMP & $-0.3 \%$ & $-0.4 \%$ & $-0.2 \%$ & $-0.2 \%$ & $-0.7 \%$ \\
Start-up costs & $4.4 \%$ & $15.3 \%$ & $0.3 \%$ & $-2.8 \%$ & $-3.3 \%$ \\
\hline \hline Institutions with $*$ are non-significant at $10 \%$ significance level & \\
\hline
\end{tabular}

Table 10: Predicted increase in unemployment: contribution of shocks and institutions

We turn now to the contribution of the different institutions to the unemployment increase over the period, for Italy and five other OECD countries. Table 10 shows that the predictive power of the regression with identified shocks and time-constant institutions is generally better than the one with common shocks.

The figures in the table have to be taken with extreme caution: employment protection legislation is non-significantly different from zero and has reverse sign. So are two of the three variables included in the union activity group. Of the rest of significant variables, ALMP and the tax wedge have a negative sign in the regression, instead of the expected positive one.

There is a general decrease in the contribution to the unemployment change of the benefit system (i.e. in Italy, now the figure is $-3.2 \%$, compared to the $-11.28 \%$ in the regression with common unidentified shocks) now that shocks have been identified. Secondly, the contribution of start-up costs, now that are interacted with identified shocks, to the unemployment rise is very large. That contribution is two times as large as the already important contribution of start-up costs when shocks were not specified in Italy and Belgium, and approximately the same in Japan, UK and USA. 
Taking the results with caution due to the numerous missing values in the data-set, start-up costs emerge as a relevant variable to explain unemployment given the shift of employment from non-services to services experienced by most western economies over the last decades.

\subsection{Time-varying institutions}

We have also run the regressions with common shocks and time-varying institutions. The data come from N\&N. ${ }^{1819}$ There are at least three problems with those regressions, though. First, there are comparable start-up cost data across OECD countries for one year only, 1998. Moreover, there are so many missing values in the measure of minimum wages that it would be advisable to use the time-constant value of minimum wage instead of the time-varying one. Therefore, start-up costs and the wage floor are time-constant while all the rest of the variables are time-varying (although some do not vary that much). The second, smaller, drawback is that time-varying data are available only for six labour market institutions, instead of the eight used above. Union coverage and active labour market policies are left out of the time-varying analysis. Given that the explanatory variables are not entirely independent one of another, this omission could affect the results.

Last but not least, institutions change very slowly over time so the value of one institution in a country at a certain period is certainly correlated with the value of the same institution at the previous or posterior period. This means that the institutions' coefficients could be biased. Indeed, one general feature of all regressions using time-varying data on institutions is that the estimated coefficients are larger, sometimes much larger, than those estimated with time-constant institutions. We suspect that this problem could be behind some change of signs. Hence, all interpretations have to be done with caution.

The tables and a more detailed analysis are available in Lopez-Garcia [2003]. The unemployment and manufacturing regressions replicate in gen-

\footnotetext{
${ }^{18}$ Although the definition and construction of the variables in N\&N are very similar to the ones in $\mathrm{B} \& \mathrm{~W}$, there are slight differences. Maybe the most important one is the construction of the benefit duration index. B\&W use the number of years of entitlement. $N \& N$ use a weighted average of the replacement rates at different moments of the unemployment spell.

${ }^{19}$ We have run the regressions with yearly data (485 observations) and five-year average periods as before. The results are very similar in both cases.
} 
eral terms those using time-constant institutions. The service regression presents some changes. The benefit replacement rate and EPL, which were significantly decreasing service employment with time-constant institutions, are now positive and, in some regressions, significant. There are three possible explanations to the positive sign of EPL and benefit replacement rate: the time evolution of both variables has been favorable to service job creation; there is a spurious relationship between the rise in service employment and the rise in both institutions; or there is a problem of biased coefficients.

To include in the analysis the variation over time of labour and product market institutions is necessary. This is only a first attempt in that direction, which shows that the main results obtained with time-constant institutions are robust. But better data and further econometric work are called for.

\section{Conclusion}

The focus of this paper has been on a macroeconomic shock surprisingly neglected in the literature, namely, the differential productivity growth in the manufacturing and the service sector. The importance of that shock is that it helps to explain the observed employment shift from non-services to the service sector. We argue that countries that had unfriendly institutions to service job creation were not able to have a smooth transition towards a service economy with the result of higher unemployment. Given the characteristics of the service employment, created in small firms at the local level, one institution that possibly hampered service employment is the administrative burdens on firm creation. Thus the second contribution of the paper is to include in the analysis, along with the usual suspects, the start-up costs of firms.

The estimations seem to support the working hypotheses of the paper: countries with higher start-up costs have significantly lower service employment and higher unemployment. This is so when no shocks are specified, and time dummies are included instead, and when the shocks are identified and include the differential productivity growth in manufacturing and services.

The first set of regressions use time dummies instead of fully specified shocks to be able to isolate the impact of the institutions from that of shocks on unemployment. The time dummies alone would be able to explain an increase in unemployment of 7 percentage points in a country with the crosscountry average value of institutions. The country with the highest start-up 
costs among all OECD countries, Italy, would be penalized with an additional increase in unemployment of $1.07 \%$. When the contribution of each institution to the predicted increase in unemployment is estimated for the case of Italy, start-up costs emerge as the largest contributor to the unemployment rise. On the other hand, employment protection legislation, one of the traditional main suspects, appears to have contributed in less than 1 percentage point to the overall increase.

Among the three macroeconomic shocks included in the analysis, shift in labour demand, increase in the interest rate and change in the manufacturing to service labour productivity, the only significant one is the latter. Again looking at the case of Italy, it has been estimated that the shift of employment to the service sector can explain alone 5 percentage points of the overall predicted increase in unemployment, which accounts for around $60 \%$ of the total. The other two shocks together can hardly explain one percent of the unemployment increase.

The analysis of the contribution of each institution, when interacted with the shocks, has to be taken with extreme caution given the restricted sample size. Still, start-up costs emerge again as the institution that has contributed the most to the predicted unemployment increase. In the case of Italy, that contribution is now twice as large as it was when no shocks were specified and time dummies were used instead.

In spite of the incomplete data on sector labour productivity, the analysis shows that the administrative burdens on firm creation and other product market regulations can be blamed for part of the increase in unemployment experienced by most western economies in the last three decades. That impact is specially important when the size of the employment shift from the agriculture and industry sector into the service sector is taken into account.

Spain, Italy or France are countries with unfriendly institutions when it comes to service job creation. Thus, policy intervention in this respect could potentially have an important impact on their labour market performance.

Further work is needed to improve the data-set, with better sector TFP data and time-varying information on start-up costs. 


\section{References}

[1] Baumol, W. J. (1967): "Macroeconomics of Unbalanced Growth: The Anatomy of Urban Crisis", The American Economic Review 57(3): 415426.

[2] Baumol, W.J., Blackman, S.A. and E.N. Wolff (1985): "Unbalanced Growth Revisited: Asymptotic Stagnancy and New Evidence", The American Economic Review 75(4): 806-817.

[3] Bean, C.R., Layard, P.R.G. and S.J. Nickell (1986) "The Rise of Unemployment: A Multi-Country Study", Economica 53(210), Supplement: Unemployment: S1-S22.

[4] Bernard, A. B. and C. Jones (1996a): "Productivity across Industries and Countries: Time Series Theory and Evidence", The Review of Economics and Statistics 78(1): 135-146.

[5] Bernard, A. B. and C. Jones (1996b): "Comparing Apples and Oranges: Productivity Convergence and Measurement across Industries and Countries", American Economic Review 86(5): 1216-1238.

[6] Blanchard, O. (1999): European Unemployment: The Role of Shocks and Institutions, Baffi Lecture, Rome.

[7] Blanchard, O. and J. Wolfers (2000): "The Role of Shocks and Institutions in the Rise of European Unemployment: The Aggregate Evidence", The Economic Journal 110: C1-C33.

[8] Bruno, M. And J. Sachs (1985): Economics of Worldwide Stagflation, Cambridge, Massachusetts: Harvard University Press.

[9] Djankov, S., La Porta, R. Lopez-Silanes, F and A. Schleifer (2000): "The Regulation of Entry", NBER Working Paper N. 7892.

[10] Fuchs, V. (1968): The Service Economy, Columbia University Press, New York.

[11] Kongsamut, P., Rebelo, S. and D. Xie (2001): "Beyond balanced growth", Review of Economic Studies 68: 869-882. 
[12] Krueger, A. and S. Pischke (1997): "Observations and Conjectures on the U.S. Employment Miracle", NBER Working Paper N. 6146.

[13] Lazear, E. (1990): "Job Security Provisions and Employment", Quarterly Journal of Economics 105(3): 699-725.

[14] Lopez-Garcia, P (2003): "Labour Market Performance and Startup Costs: OECD Evidence" CESIFO 849 (January). Available at http://papers.ssrn.com/sol3/papers.cfm?abstract_id=382921

[15] Marimon, R. and F. Zilibotti (1998): "Actual versus Virtual Employment in Europe: Is Spain Different?", European Economic Review 42(1): 123-153.

[16] Mckinsey Global Institute (1994): Employment Performance, Mckinsey \& Inc. Washington D.C. November.

[17] Milner, S., Metcalf, D. and G. Nombela (1995): "Employment Protection Legislation and Labour Market Outcomes in Spain", Centre for Economic Performance, London School of Economics, Discussion Paper N. 244.

[18] Nickell, S. (1997): "Unemployment and Labor market Rigidities: Europe versus North America", The Journal of Economic Perspectives 11(3): $55-74$.

[19] Nickell,S. And L. Nunziata (2002): "Unemployment in the OECD since the 1960s. What Do We know?", Mimeo, Bank of England.

[20] Nicoletti, G., Scarpetta, S. and O. Boylaud (2000): "Summary Indicators of Product Market Regulation with an Extension to Employment Protection Legislation", OECD Economics Department Working Papers N.226.

[21] OECD (1993): Employment Outlook, Organisation for Economic CoOperation and Development. Paris.

[22] OECD (1994): Jobs Study: Facts, Analysis and Strategies, Organisation for Economic Co-Operation and Development. Paris.

[23] OECD (1996): Employment Outlook, Organisation for Economic CoOperation and Development. Paris. 
[24] OECD (1997): Employment Outlook, Organisation for Economic CoOperation and Development. Paris.

[25] OECD (1998): Fostering Entrepreneurship, Organisation for Economic Co-Operation and Development. Paris.

[26] OECD (2000): Employment Outlook, Organisation for Economic CoOperation and Development. Paris.

[27] Phelps, E. (1994): Structural Slumps. The Modern Equilibrium Theory of Unemployment, Interests and Assets, Cambridge MA: Harvard University Press.

[28] Scarpetta, S., P. Hemmings, Tressel, T. and J. Woo (2002): "The Role of Policy and Institutions for Productivity and Firm Dynamics: Evidence from Micro and Industry Data”, OECD Economics Department Working Papers N. 329.

[29] Reynolds, P.D., Camp, S.M., Bygrave, W.D. and E.Autio (2001): Global Entrepreneurship Monitor Executive Report. www.gemconsortium.org.

[30] Siebert, H. (1997): "Labor Market Rigidities: At the Root of Unemployment in Europe", The Journal of Economic Perspectives 11(3): 37-54. 


\section{CENTRE FOR ECONOMIC PERFORMANCE \\ Recent Discussion Papers}

564 A. Manning

563 D. Quah

562 H. Gospel

P. Willman

561 L. R. Ngai

560 M. J. Conyon

R. B. Freeman

559 R. B. Freeman

R. Schettkat

558 R. B. Freeman

557 R. B. Freeman

556 M. Guttil rrez-DomPnech

555 H. Gospel

J. Foreman

554 S. Machin

553 J. Blanden

S. Machin

552 D. Devroye

R. B. Freeman

551 M. Guadalupe
The Real Thin Theory: Monopsony in Modern Labour Markets

Digital Goods and the New Economy

High Performance Workplaces: the Role of Employee Involvement in a Modern Economy. Evidence on the EU Directive Establishing a General Framework for Informing and Consulting Employees

Barriers and the Transition to Modern Growth

Shared Modes of Compensation and Firm

Performance: UK Evidence

Marketization of Production and the US-Europe Employment Gap

The Labour Market in the New Information Economy

Institutional Differences and Economic Performance Among OECD Countries

The Impact of the Labour Market on the Timing of Marriage and Births in Spain

The Provision of Training in Britain: Case Studies of Inter-Firm Coordination

Factors of Convergence and Divergence in Union Membership

Cross-Generation Correlations of Union Status for Young People in Britain

Does Inequality in Skills Explain Inequality of Earnings Across Advanced Countries?

The Hidden Costs of Fixed Term Contracts: the Impact on Work Accidents 
City Size Distribution as a Consequence of the Growth Process

549 S. Redding

A. J. Venables

Explaining Cross-Country Export Performance: International Linkages and Internal Geography

548 T. Bayoumi M. Haacker

547 A. B. Bernard

S. Redding

P. K. Schott

H. Simpson

546 M. GutiPrez-Dom nech

Employment Penalty After Motherhood in Spain

545 S. Nickell

S. Redding

J. Swaffield

It's Not What You Make, It's How You Use IT:

Measuring the Welfare Benefits of the IT Revolution Across Countries

Factor Price Equalization in the UK?

544 S. Machin
A. Manning
J. Swaffield

543 R. Belfield

D. Marsden

542 C. A. Pissarides

541 M. Amiti

C. A. Pissarides

Educational Attainment, Labour Market Institutions and the Structure of Production

Where the Minimum Wage Bites Hard: the Introduction of the UK National Minimum Wage to a Low Wage Sector

Matchmaking: the Influence of Monitoring Environments on the Effectiveness of Performance Pay Systems

Consumption and Savings With Unemployment Risk: Implications for Optimal Employment Contracts

Trade and Industrial Location with Heterogeneous Labor

540 G. Duranton

H. G. Overman

Testing for Localisation Using Micro-Geographic Data

539 D. Metcalf

Unions and Productivity, Financial Performance and Investment: International Evidence

$538 \quad$ F. Collard

Spanish Unemployment Persistence and the Ladder

R. Fonseca Effect

R. MuZoz

To order a discussion paper, please contact the Publications Unit Tel 02079557673 Fax 02079557595 Email info@ cep.lse.ac.uk Web site http://cep.lse.ac.uk 